\title{
Identification of the Major Fungitoxic Component of Cinnamon Bark Oil
}

\author{
Gulab N. Jham¹, Onkar D. Dhingra², Carolina M. Jardim¹ \& Vânia M. M. Valente ${ }^{1}$ \\ 'Departamento de Química, Laboratório de Pesquisa em Produtos Naturais, e-mail: gulab@ufv.br. 2Departamento de \\ Fitopatologia, e-mail: dhingra@ufv.br, Universidade Federal de Viçosa, Viçosa, MG, CEP 36571-000
}

(Accepted for Publication 24/05/2005)

Corresponding Author: Onkar D. Dhingra

JHAM, G.N., DHINGRA, O.D., JARDIM, C.M. \& VALENTE, V.M. Identification of the major fungitoxic component of cinnamon bark oil. Fitopatologia Brasileira 30:404-408. 2005.

\begin{abstract}
The study was done to identify the most active fungitoxic component of cinnamon bark (Cinnamomum zeylanicum) oil that can be used as a marker for standardization of cinnamon extract or oil based natural preservative of stored seeds. Aspergillus flavus and A. ruber were used as test fungi. The hexane extracted crude oil and the hydro-distilled essential oil from cinnamon bark had complete growth inhibition concentration (CGIC) of 300 and $100 \mu 1 / 1$, respectively. Both oils produced three fractions on preparative thin layer silica-gel chromatography plates. The fraction-2 of either oil was the largest and most active, with CGIC of $200 \mu \mathrm{l} / 1$, but the fungitoxicity was also retained in the other two fractions. The fraction- 1 and 3 of the crude oil reduced growth of both the fungal species by $65 \%$, and those of distilled oil by $45 \%$ at 200 $\mu 1 / 1$. The CGIC of these fractions from both the sources was above $500 \mu 1 / 1$. The gas chromatography and mass spectrometry (GC-MS) of the fraction-2 of the hexane extract revealed that it contained $61 \%$ cinnamaldehyde, $29 \%$ cinnamic acid, and two minor unidentified compounds in the proportion of $4 \%$ and $6 \%$. The GC-MS of the fraction- 2 of the distilled oil revealed that it contained $99.1 \%$ cinnamaldehyde and $0.9 \%$ of an unidentified compound. The CGIC of synthetic cinnamaldehyde was $300 \mu \mathrm{l} / \mathrm{l}$ and that of cinnamic acid above $500 \mu \mathrm{l} / \mathrm{l}$. The 1:1 mixture of cinnamaldehyde and cinnamic acid had CGIC of $500 \mu 1 / 1$. The data revealed that cinnamaldehyde was the major fungitoxic component of hexane extract and the distilled essential oil of cinnamon bark, while other components have additive or synergistic effects on total fungitoxicity. It is suggested that the natural seed preservative based on cinnamon oil can be standardized against cinnamaldehyde.
\end{abstract}

Additional keywords: essential oils, antifungal activity, fungitoxicity, active compounds, cinnamon oil, seed preservative.

\begin{abstract}
RESUMO
Identificação do principal composto fungitóxico de óleo de casca de canela

O objetivo deste estudo foi identificar o mais ativo componente fungitóxico de óleo de casca de canela (Cinnamomum zeylanicum), que pode ser usado como marcador para padronização de um conservante natural, baseado no óleo de canela, para sementes armazenadas. Os dois fungos de armazenamento, Aspergillus flavus e A. ruber foram usados como fungosteste. $\mathrm{O}$ extrato de hexano e o óleo obtido por meio de hidro-destilação de casca de canela, tiveram concentração de inibição completa de crescimento (CICC) de 300 e $100 \mu \mathrm{l} / 1$, respectivamente. A cromatografia preparativa de camada delgada de ambos os óleos produziu três frações. Em ambos os óleos a fração-2 foi a maior e mais ativa com CICC de 200 $\mu 1 / 1$. A fungitoxidez também foi encontrada nas outras duas frações de ambos os óleos. As frações 1 e 3 do óleo extraído com hexano reduziram o crescimento de ambas as espécies de Aspergillus em 65\%, e do óleo destilado em 45\%, com CICC maior que $500 \mu \mathrm{l} / \mathrm{l}$. A cromatografia gasosa-espectrometria de massa revelou que frações-2 de óleo hexânico continha $61 \%$ de cinamaldeído, $29 \%$ de ácido cinâmico e dois compostos não identificados nas proporção de 4 e $6 \%$. A fracão-2 do óleo destilado continha $99,1 \%$ de cinamaldeído e $0,1 \%$ de um composto não identificado. O CICC de cinamaldeído sintético foi de $300 \mu \mathrm{l} / 1$ e de ácido cinâmico $500 \mu \mathrm{l} / \mathrm{l}$. Os dados revelam que cinamaldeído é o composto principal com atividade antifúngica tanto no óleo extraído com hexano quanto no óleo destilado da casca de canela. Os outros componentes parecem ter efeito aditivo ou sinérgico na atividade fungitóxica total. O conservante natural de sementes baseado no óleo ou extrato de canela pode ser padronizado utilizando cinamaldeído como marcador.
\end{abstract}

Palavras-chave adicionais: óleos essenciais, atividade antifúngica, fungitoxidez, compostos ativos, óleo de canela, conservante sementes.

\section{INTRODUCTION}

Fungal deterioration of stored seeds and grains is a chronic problem in the Brazilian storage system because of the warm and humid climate. Under such conditions these products are colonized by various species of Aspergillus leading to deterioration and mycotoxin formation. There is no practical, cost-effective, and non-toxic method available for preventing fungal deterioration of these commodities. Therefore use of non-toxic edible substances to control fungal 
deterioration of the stored grains and seeds is highly desirable. Several edible botanical extracts have been reported to have antifungal activity (Ferhout et al., 1999; Mastura et al, 1999; De et al., 1999; Pradeep et al., 2003).

The bark and the leaves of Cinnamomum spp. are commonly used as spices in home kitchens and their distilled essential oils or synthetic analogs are used as flavoring agent in the food and beverage industry. Although traditionally known, some recent scientific studies have shown antimicrobial activity of essential oils of Cinnamomum cassia Presl., C. osmophloeum Kaneh. and C. zeylanicum Blume (Tiwari \& Tiwari, 1997; Ferhout et al. 1999; Mastura et al. 1999; De et al., 1999; Chang et al., 2001). Quattara et al. (1997) reported the inhibitory effect of $C$. zeylanicum essential oil on meat deteriorating organisms. Antifungal activity was reported for respiratory tract infecting fungi such as Aspergillus niger Tieghem, A. fumigatus Fres., A. nidulans (Eidam) Winter and A. flavus Link (Singh et al., 1995). Treating high moisture barley (Idler et al., 1996) or wheat (Triticum aestivum L.) grains (Scholz et al., 1999) with essential oil of $C$. zeylanicum protected them from deteriorating fungi and ochratoxin formation. Similar findings were reported for protection of stored maize (Zea mays L.) against A. flavus (Monte-Belmont \& Carvajal, 1998).

The C. zeylanicum tree is endemic in Brazil, and our initial exploratory studies have shown that hexane extract of $C$. zeylanicum bark protected high moisture soybean (Glycine max L.) and wheat grains from storage fungi (unpublished data). The chemical composition of the essential oil or hexane extract of $C$. zeylanicum is not well known, and there appears to be very high variability depending upon the year, climate, production area and the tree chemotype (Koketsu et al., 1997; Jirovetz et al., 1998; Mallavarapu et al., 2000; Raina et al., 2001). The essential oil of bark from trees grown in the State of Paraná was found to have cinnamaldehyde constituting on average, $55 \%$ of the total oil. However, there were considerable difference among the individual trees (Koketsu et al., 1997). The findings of Chang et al. (2001) showed that such differences might be responsible for the varied antimicrobial activity of the essential oil. While the essential oil obtained from one tree of C. osmophloeum showed strong antimicrobial activity, that from another tree did not show any activity. The chemical analysis of the oils from both the sources revealed that the active oil contained $74 \%$ cinnamaldehyde, compared to only $8.3 \%$ in the inactive oil. Such variations of the antimicrobial activity and chemical composition of essential oil obtained from different trees can be a stumbling block for developing a reliable product for use

The extract or essential oil of $C$. zeylanicum stem bark is composed of a number of compounds and not all of them appear to have antimicrobial activity. Therefore, for developing a reliable ready-to-use product it is necessary to identify the most active component(s) against which the final product can be a standardized. The following study was done to identify the most active antifungal fraction of C. zeylanicum bark distilled essential oil and the hexane extract.

\section{MATERIALS AND METHODS}

\section{Preparation of hexane extract and distilled oil}

Locally produced cinnamon bark was purchased from the local spice store. All the chemical and solvents used in the study were analytical grade and distilled before use. Cinnamon bark was ground to pass through a 1-mm screen and the powder obtained was extracted at room temperature by constant percolation with hexane until all the hexane soluble components were removed. The solvent was evaporated using a rotatory evaporator, under vacuum, at $35{ }^{\circ} \mathrm{C}$. The bark essential oil was obtained by hydrodistillation for $6 \mathrm{~h}$. The distillate was extracted twice with dichloromethane, including water soluble or dispersed components, dried over anhydrous sodium sulfate, and the dichloromethane was evaporated using the rotary evaporator under vacuum. The hexane extract and the distilled oil were stored in airtight screw capped vials at $-10{ }^{\circ} \mathrm{C}$ until use.

\section{Fractionation of the hexane extract and the distilled oil}

The hexane extract and the distilled oil were fractionated by preparative silica gel thin layer chromatography (TLC) using $20 \times 20 \mathrm{~cm}$ silica gel plates (ca. $1 \mathrm{~mm}$ thick layer, 60GF, Merck). Several TLC plates were used to obtained workable quantities of the fractions. The crude extract or distilled oil (200 mg) was applied on each plate, which was then developed with hexane: dichloromethane $(1: 9 \mathrm{v} / \mathrm{v})$. To visualize the fractions, a small edge of the TLC plate was sprayed with phosphomoliblinin acid followed by 5-min heating with hot air using an electric hair drier. The fractions that did not react were scraped off and transferred to a beaker and extracted with dichloromethane for two hours with constant stirring. The mixture was filtered and the dichloromethane was evaporated in a rotary evaporator under vacuum, weighed and stored at $-10{ }^{\circ} \mathrm{C}$ until use.

\section{Bioassays}

The antifungal activity of all the tests materials (hexane extract, distilled oil and their TLC fractions) was determined by the use of "food poisoning technique" (Dhingra \& Sinclair, 1995). Each extract or its fraction was tested at concentrations of 50 to $500 \mu \mathrm{l} / \mathrm{l}$ at the intervals of $50 \mu \mathrm{l} / \mathrm{l}$, to determine the complete growth inhibition concentration (CGIC). The test material was dissolved in methanol in proportion of $1: 1$, and the required amount was added to the cool molten potato dextrose agar which was then shaken vigorously, and poured into $9-\mathrm{cm}$ diameter culture plates. The medium containing $250 \mu \mathrm{l} / 1$ methanol served as control. The medium in each plate was seeded with a 5-mm water-agar culture disc of A. flavus Link or A. ruber Link, and incubated at $25^{\circ} \mathrm{C}$ for ten days, when 
the colony diameter was measured. The growth inhibition was expressed as the percentage of the colony diameter in the control plates. All the bioassays were done in four replicates and repeated.

\section{Characterization of active fraction}

The most active fraction of the hexane extract and the distilled oil was characterized by gas chromatographymass spectrometry (GC-MS), using a Shimadzu QP5000 system equipped with a data base with 250,000 compounds, auto-sampler, fused silica capillary column coated with DB1 stationary phase $(30 \mathrm{~m} \times 0.25 \mathrm{~mm} ; 0.25 \mu \mathrm{m}$ film thickness, $\mathrm{J} \& \mathrm{~W}$. Scientific). The GC oven temperature was raised from 40 to $320{ }^{\circ} \mathrm{C}$ at the rate of $4{ }^{\circ} \mathrm{C} / \mathrm{min}$. Helium gas was used as the carrier for all the analysis, and electron ionization mass spectra $(70 \mathrm{eV})$ were recorded by scanning from $\mathrm{m} / \mathrm{z}$ 29 to 500. The injector and transfer line temperatures were maintained at $220{ }^{\circ} \mathrm{C}$ and $280{ }^{\circ} \mathrm{C}$, respectively. One microliter of each sample was injected in the split mode $(100: 1)$.

\section{RESULTS AND DISCUSSION}

The hexane extract and the distilled oil showed CGIC of $300 \mu \mathrm{l} / \mathrm{l}$ and $100 \mu \mathrm{l} / \mathrm{l}$ for both species of Aspergillus, which is much lower than the reported $2000 \mu \mathrm{l} / 1$ (Mishra et al, 1992) and $400 \mu 1 / 1$ (Tiwari \& Tiwari, 1997).

The preparative TLC fractionation of hexane extract yielded three fractions, representing $58.5 \%$ (w/w) of the crude extract. The fraction- 2 represented $77 \%$ of the total yield, which corresponds to $45 \%$ of the crude extract. The fractions 1 and 3, each represented $11.5 \%$ of the total yield, corresponding to about $6.75 \%$ each of the crude extract. The fraction- 2 was most active against both the test fungi with CGIC of $200 \mu 1 / 1$, which is $33 \%$ less than the CGIC of the crude extract. The fractions -1 and 3 reduced growth by an average of $65 \%$ at $200 \mu \mathrm{l} / \mathrm{l}$. The CGIC of either of these fractions was higher than $500 \mu \mathrm{l} / \mathrm{l}$, since the growth was reduced only by $90 \%$ at this concentration. The lower CGIC of fraction- 2 compared to the crude extract suggests that it contained the major antifungal component of the hexane extract of $C$. zeylanicum bark. The other two fractions also contained antifungal components of lower activity.

Similar to the hexane extract, the preparative TLC of the distilled oil also yielded three fractions, with a combined yield of $97.5 \%$ of the crude distilled oil. The fraction- 2 represented the $70 \%$ of the total yield, which corresponds to $71.8 \%$ of the crude distilled soil. The fraction1 and 3 made up 21 and $6.5 \%$ of the total yield, corresponding to 21.5 and $6.6 \%$, respectively of the crude distilled oil. Similar to the hexane extract, the fraction- 2 was most active against both the test fungi with CGIC of $200 \mu 1 / 1$, which is twice the CGIC of the crude distilled oil. This behavior of the distilled oil and its fraction- 2 is similar to the crude hexane extract. At $200 \mu 1 / 1$ both, the fraction- 1 and 3 reduced fungal growth by an average of $43 \%$, which is considerably lower than the corresponding fractions of the hexane extract. Like fractions- 1 and 3 of the hexane extract the CGIC of these fractions was also above $500 \mu \mathrm{l} / 1$ as the growth was reduced only by $74 \%$, which is also lower than the same fractions of hexane extract. These data show that the major antifungal component of the distilled oil, similar to the hexane extract, was retained in the fraction- 2 .

The GC/MS of the fraction- 2 of the hexane extract yielded four peaks, with relative intensity of $4,61,6$, and $29 \%$. The first and second most intense peaks were identified as cinnamaldehyde and cinnamic acid, respectively (Figure 1A). The remaining two peaks with relative intensity of $6 \%$ or less could not be identified. The GC/MS of the fraction2 of the distilled oil yielded only one peak with a relative intensity of $99.1 \%$, which was identified as cinnamaldehyde (Figure 1B).

Since the most fungitoxic fraction- 2 of the hexane extract consisted mainly of cinnamaldehyde and cinnamic acid, and only the former was found in the same fraction of distilled oil, antifungal activity of the synthetic analog of cinnamaldehyde and cinnamic acid was tested separately and in 1: 1 mixture. The synthetic cinnamaldehyde had CGIC of $300 \mu \mathrm{l} / \mathrm{l}$, which is $33 \%$ higher than the fraction-2 of distilled oil, which contained $99.1 \%$ cinnamaldehyde, and also of hexane extract which contained $61 \%$ of cinnamaldehyde. At $300 \mu \mathrm{l} / 1$ the synthetic cinnamic acid reduced growth only by $26 \%$, and its CGIC appears to be much above $500 \mu \mathrm{l} / 1$ since the growth at this concentration was reduced only by $36 \%$. On the other hand, CGIC of $1: 1$ mixture of these compounds was $500 \mu \mathrm{l} / 1$, which is also much higher than that of the crude hexane extract and crude distilled oil and their corresponding fractions-2. The similarity of CGIC value of the fractions- 2 of the hexane extract which contained about $61 \%$ cinnamaldehyde and $29 \%$ cinnamic acid, and of the fraction- 2 of the distilled oil, which contained $99.1 \%$ cinnamaldehyde, was rather intriguing and could not be explained by the data from this

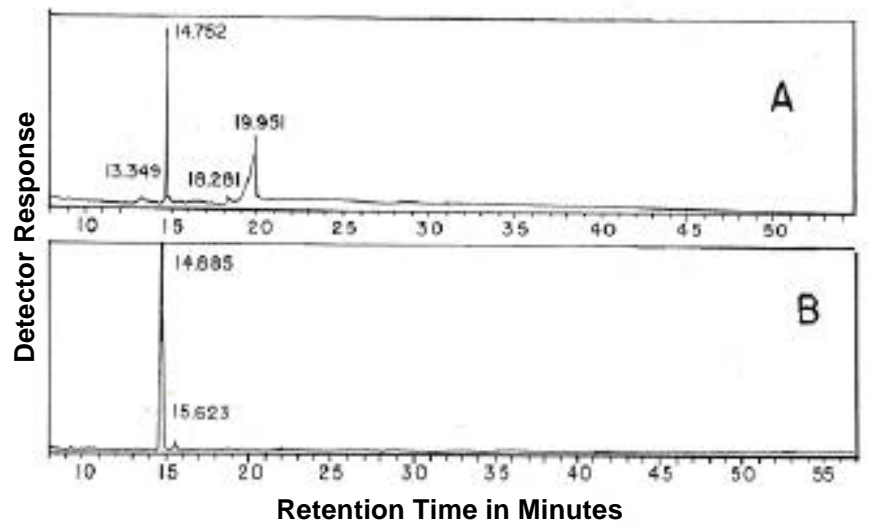

FIG. 1 - A total ion chromatogram obtained by gas chromatographymass spectrometry (GC-MS) analysis of the most active fraction-2 from preparative silica gel thin layer chromatography of the hexane extract (A) and the distilled essential oil (B). 
study. However, these data clearly suggest that although the cinnamaldehyde is the major fungitoxic component of the C. zeylanicum bark distilled oil, and cinnamic acid present in the hexane extract may act as a secondary component, total fungitoxic activity of either hexane extract or the distilled oil involves others components whose presence may be additive or synergistic to the activity of these two components.

The lower CGIC of the fraction-2 of the distilled oil or the hexane extract compared to the synthetic cinnamaldehyde is similar to that reported by Chang et al. (2001) who showed that antibacterial activity of synthetic cinnamaldehyde was $50 \%$ less than that of the $C$. osmophloeum leaf distilled oil containing $77 \%$ cinnamaldehyde. The composition of $C$. zeylanicum bark distilled oil is known to differ considerably, according to region, year, climate and the tree chemotype. Chalchat \& Valade (2000) reported that $C$. zeylanicum bark distilled oil from Madagascar consisted predominantly of cinnamaldehyde and camphor, while Nath et al. (1996) found benzyl benzoate constituting $85 \%$ of the oil distilled from tree bark grown in northeast India, and the GC/MS revealed seventeen components. On the other hand, Jirovetz et al. (1998) reported eugenol as the major (85\%) component of bark distilled oil from Cameroon. The bark essential oil from Paraná was found to have about $55 \%$ cinnamaldehyde (Koketsu et al., 1992). Such large differences in the chemical compositions of the distilled oil may explain the large difference of the CGIC for fungal growth obtained in this study and by other workers (Mishra et al. 1992; Tiwari \& Tiwari, 1997). This study, however, did not aim at determining the total composition of distilled or hexane extracted oil from Brazilian C. zeylanicum, but to identify the most active fungitoxic compound that can be used as standardizing marker for product development. It is possible that benzyl benzoate may have some toxic activity, and it separated from the crude extract or oil to the fraction 1 or 3. Ross (1976) reported eugenol, known for its antimicrobial activity, as one of the major components of bark distilled oil along with cinnamaldehyde, which constituted 50 to $70 \%$ of the total essential oil. Eugenol, if present in the extracts, may have separated as indicated by fungicidal activity of fraction 1 and 3, although at a much lower level. Due to the large variation in the chemical composition of $C$. zeylanicum bark oil it is rather difficult to compare the findings of this study to those of the others. On the other hand, since in most studies cinnamaldehyde was found to constitute more than $50 \%$ of the total essential oil, it would be safe to assume that this compound is the major fungitoxic component of the C. zeylanicum oil. According to Chang et al. (2001), cinnamaldehyde has good antibacterial activity with CGIC ranging from 250 to $500 \mu \mathrm{l} / 1$ depending upon the bacterial species, while the cinnamic acid showed CGIC of $1000 \mu \mathrm{l} /$ 1 , which is two to four times higher than that of cinnamaldehyde. These results corroborate the findings of this study where cinnamaldehyde showed much higher fungitoxic activity than the cinnamic acid.

In conclusion this study shows that non-toxic seed and grain preservatives can be developed by sourcing the raw material from high cinnamaldehyde chemotype trees, and both the distilled oil or hexane extracted oil may be equally useful for the final product which should be standardized against cinnamaldehyde.

\section{LITERATURE CITED}

CHALCHAT, J.C. \& VALADE, I. Chemical composition of leaf oils of Cinnamomum from Madagascar:C. zeylanicum Blume, $C$. camphora L., C. fragrans Baillon and C. angustifolium. Journal of Essential Oil Research 12:537-540. 2000.

CHANG, S.T., CHEN, P.F. \& CHANG, S.C. Antimicrobial activity of leaf essential oils and their constituents from Cinnamomum osmophloeum. Journal of Ethnopharmacology 77:123-127. 2001.

DE, M., DE, A.K. \& BANERJEE A.B. Antimicrobial screening of some Indian spices. Phytotherapy Research 13:616-618. 1999. DHINGRA, O.D. \& SINCLAIR, J.B. Basic Plant Pathology Method 2nd ed. CRC Lewis Publishers, Boca Raton, Florida, USA. 1995.

FERHOUT, H., BOHATIER, J., GUILLOT, J. \& CHALCHAT, J.C. Antifungal activity of selected essential oils, cinnamaldehyde and carvacrol against Malassezia furfur and Candida albicans. Journal of Essential Oil Research 11:119-129. 1999.

IDLER. C., EHRICH, J., HAGEMANN, L. \& FUCHS, H. [The preservation of feed grain by spice oils]. Wirtschaftseigene-Futter 42:137-142. 1996.

JIROVETZ, L., BUCHBAUER, G., NGASSOUM, M. B. \& EBERHARDT, R. Analysis and quality control of the essential oil of the leaves of Cinnamomum zeylanicum L. from Cameroon. Ernährung 22:443-445. 1998.

KOKETSU, M., GONCALVES, S.L., GODOY, R.L.O., LOPES, D. \& MORSBACH, N. Óleos essenciais de cascas e folhas de canela (Cinnamomum verum Presl) cultivada no Paraná. Ciência e Tecnologia de Alimentos 17:281-285. 1997.

MALLAVARAPU, G.R. \& RAMESH, S. Essential oil of the fruits of Cinnamomum zeylanicum Blume. Journal of Essential Oil Research 12:628-630. 2000.

MASTURA, M., AZAH, M., KHOZIRAH, S., MAWARDI, R. \& MANAF, A.A. Anticandidal and antidermatophytic activity of Cinnamomum species essential oils. Cytobios 98:17-23. 1999.

MISHRA, M., MALIK, S.S., TEWARI, S.N. \& TAURO, P. Allelopathic effect of certain botanicals against six fungal pathogens of rice. In: Narwal, S.S. (Ed.). Proceedings First National Symposium. Allelopathy in agroecosystems (agriculture \& forestry) Indian Society of Allelopathy. 1992. pp.191-193.

MONTE-BELMONT, R. \& CARVAJAL, M. Control of Aspergillus flavus in maize with plant essential oils and their components. Journal of Food Protection 61:616-619. 1998.

NATH, S.C., PATHAK, M.G. \& BARUAH, A. Benzyl benzoate, the major component of the leaf and stem bark oil of Cinnamomum zeylanicum Blume. Journal of Essential Oil Research 8:327-328. 1996.

PRADEEP, A.G., LOKESH, S., \& RAI, V.R. Efficacy of some essential oils on seed mycoflora and seedling quality of some crop species saved by farmers. Advances in Plant Sciences 16:53- 
58:2003.

QUATTARA, B., SIMARD, R.E., HOLLY, R.A., PIETTE, G.J.P. \& BEGIN, A. Antibacterial activity of selected fatty acids and essential oils against six meat spoilage organisms. International Journal of Food Microbiology 37:155-162. 1997.

RAINA, V.K., SRIVASTAVA, S.K., AGGARWAL, K.K; RAMESH, S. \& KUMAR, S. Essential oil composition of Cinnamomum zeylanicum Blume leaves from Little Andaman, India. Flavour \& Fragrance Journal 16:374-376. 2001

ROSS, M.S.F. Analysis of cinnamon oils by high-pressure liquid chromatography. Journal of Chromatography 118:273-275. 1975.
SCHOLZ, K., VOGT, M., KUNZ, B. \& LYR, H. Application of plant extracts for controlling fungal infestation of grains and seeds during storage. In: Russell, P.E. \&. Dehne, H.W (Eds.) Modern fungicides and antifungal compounds II. Intercept Limited; Andover, U.K. 1999. pp.429-435.

SINGH, H.B., SRIVASTAVA, M., SINGH, A.B. \& SRIVASTAVA, A.K. Cinnamon bark oil, a potent fungitoxicant against fungi causing respiratory tract mycoses. Allergy 50:995-999. 1995.

TIWARI, R. \& TIWARI, R. Fungitoxicity of volatile constituents of some higher plants against predominant storage fungi. Indian Phytopathology 50:548-551. 1997. 